\title{
UJI AKTIVITAS ANTIBAKTERI EKSTRAK ETANOL DAUN GLODOKAN TIANG (Polyalthia longifolia S.) TERHADAP BAKTERI Propionibacterium acnes
}

\author{
Antibacterial Activity of Ethanol Extract of Glodokan Tiang Leaves (Polyalthia longifolia S.) \\ Against Propionibacterium acnes bacteria

\section{Yulistia Budianti Soemarie, Anita Apriliana, Meita Indriastuti, Nurul Fatimah, Heri Wijaya}

Akademi Farmasi Samarinda

yulistiabudianti@ymail.com

081350896705

\begin{abstract}
One cause of acne is Propionibacterium acnes bacteria. One of the alternative to solve the problem of acne is with the use of glodokan tiang herbs (Polyalthia longifolia S.) Purpose of this study was to determine the antibacterial activity of ethanol extract of glodokan tiang leaves against Propionibacterium acnes bacteria. This research is an experimental study. The research phase begins with sample preparation, determination, extraction, phytochemical screening, and antibacterial test of ethanol extract of glodokan tiang leaves against Propionibacterium acnes. In the activity test and antibacterial test using disc diffusion method with concentration of $30 \%, 40 \%$, and $50 \%$ and Clindamycin $150 \mathrm{mg}$ as positive control and negative control of dimethyl sulfoxide is $1 \%$. The results showed that ethanol extract of glodokan tiang leaves contain secondary metabolite compounds such as alkaloids, tannins, flavonoids, and saponins. The inhibitory zones showed at 30\%, 40\%, and $50 \%$ concentrations were $8.83 \mathrm{~mm}, 9 \mathrm{~mm}$, and $10.5 \mathrm{~mm}$. Of the three concentrations, the strongest inhibition zone at $50 \%$ concentration is $10.5 \mathrm{~mm}$.
\end{abstract}

Keywords : Propionibacterium acnes, glodokan tiang (Polyalthia longifolia S.), disc diffusion method

\begin{abstract}
Abstrak
Jerawat merupakan penyakit kulit yang disebabkan oleh bakteri salah satunya bakteri Propionibacterium acnes. Penggunaan obat jerawat secara terus menerus dari bahan kimia sintetik dapat menimbulkan efek samping yang merugikan berupa resistensi. Alternatif pengobatan yang digunakan untuk mengatasi masalah jerawat adalah dengan pemanfaatan tanaman glodokan tiang (Polyalthia longifolia S.). Pemanfaatan obat dari tanaman dapat mengurangi terjadinya efek samping yang berbahaya bagi kesehatan kulit dibandingkan senyawa kimia. Tujuan dari penelitian ini adalah untuk mengetahui aktivitas antibakteri ekstrak etanol daun glodokan tiang terhadap bakteri Propionibacterium acnes. Penelitian ini merupakan penelitian eksperimental. Tahapan penelitian dimulai dengan penyiapan sampel, determinasi, ekstraksi, skrining fitokimia, dan uji antibakteri ekstrak etanol daun glodokan tiang terhadap bakteri Propionibacterium acnes. Pada uji aktivitas dan uji antibakteri menggunakan metode difusi cakram dengan konsentrasi 30\%, 40\%, dan 50\% serta kontrol positif Klindamisin $150 \mathrm{mg}$ dan kontrol negatif dimetil sulfoksida $1 \%$. Hasil penelitian menunjukkan ekstrak etanol daun glodokan tiang mengandung senyawa metabolit sekunder antara lain alkaloid, tanin, flavonoid, dan saponin. Zona hambat yang terbentuk pada konsentrasi $30 \%$, 40\%, dan 50\% secara berurut adalah 8,83 mm, $9 \mathrm{~mm}$, dan 10,5 mm. Dari
\end{abstract}


ketiga konsentrasi tersebut zona hambat yang paling kuat terdapat pada konsentrasi $50 \%$ yaitu sebesar $10,5 \mathrm{~mm}$.

Kata Kunci : Propionibacterium acnes, glodokan tiang (Polyalthia longifolia S.), metode difusi cakram.

\section{PENDAHULUAN}

Jerawat merupakan salah satu penyakit kulit yang disebabkan karena bakteri, melalui proses peradangan kronik kelenjar polisebasea yang ditandai dengan adanya komedo, papul, pustula, dan nodus. Penyebaran jerawat terdapat pada wajah, dada, punggung yang mengandung kelenjar sebasea yang umumnya terjadi pada masa remaja[1]. Bakteri penyebab jerawat diantaranya adalah Propionibacterium acnes, Staphylococcus epidermidis, dan Staphylococcus aureus [2].

Pengobatan jerawat biasanya dilakukan dengan pemberian antibiotik seperti eritromisin, klindamisin, dan tetrasiklin, namun obat-obat tersebut memiliki resistensi terhadap tubuh dan dapat mengiritasi kulit. Hal ini menjadi salah satu alasan pemberian obat jerawat dari bahan alamiah untuk mengurangi potensi terjadinya resistens i[3].

Salah satu tumbuhan yang berpotensi sebagai obat jerawat adalah glodokan tiang (Polyalthia longifolia S.) daunnya menunjukkan aktivitas antibakteri, antioksidan, antidotum, dan sitotoksik terhadap sel kanker[4]. Menurut data empiris pada penelitian terdahulu mengatakan bahwa masyarakat India menggunakan tanaman glodokan tiang (Polyalthia longifolia S.) ini sebagai penyakit kulit, keputihan, penyakit rahim, cacingan, sariawan, hipertensi, dan penyakit demam[5].

Penelitian lainnya mengungkapkan tentang aktivitas antibakteri ekstrak etanol daun glodokan tiang terhadap bakteri $S$. aureus memperlihatkan adanya zona hambat pada konsentrasi 2,5\% memiliki diameter $21 \mathrm{~mm}$ [6]. Analisis kromatografi ekstrak metanol juga mengungkapkan adanya alkaloid, flavonoid, tanin, steroid, dan glikosida. Penelitian tentang aktivitas antibakteri ekstrak metanol daun glodokan tiang pada konsentrasi $5 \%$ terhadap bakteri Bacillus subtilis memiliki zona hambat sebesar $(34.10 \pm 0.00) \mathrm{mm}$, Sarcina lutea $(44.20 \pm 0.14) \mathrm{mm}, \quad X$. campestris $(31.30 \pm 0.14) \mathrm{mm}$, Eschericia coli $(36.00 \pm 0.00) \quad \mathrm{mm}, \quad$ Klebsiella pneumoniae $(30.00 \pm 0.00) \mathrm{mm}$, Pseudomonas sp $(33.00 \pm 0.00) \mathrm{mm}[5]$. Penelitian glodokan tiang yang lain adalah tentang antivitas antibakteri ekstrak etanol daun glodokan tiang terhadap bakteri E. coli yang merupakan bakteri gram negatif, memperlihatkan adanya zona hambat pada konsentrasi $50 \%$ yakni $10,34 \mathrm{~mm}$ dengan kriteria kuat [7].

Berdasarkan latar belakang di atas dilakukan penelitian tentang uji aktivitas antibakteri ekstrak etanol daun glodokan tiang (Polyalthia longifolia S.) dengan konsentrasi $30 \%, 40 \%$ dan $50 \%$ terhadap bakteri $P$. acnes sebagai alternatif pengobatan jerawat yang mengandung bahan kimia.

\section{METODE PENELITIAN}

\section{Alat dan Bahan}

Alat yang digunakan adalah Autoclaf, incubator, laminar airflow cabinet, mikropipet ukuran 5-50 $\mu \mathrm{l}$, rotary evaporator dan alat-alat gelas lainnya

Bahan yang digunakan adalah daun glodokan tiang, Mueller Hilton Agar, Nutrient Agar, kertas cakram, etanol $70 \%$, DMSO (Dimetil Sulfoksida) $1 \% \mathrm{v} / \mathrm{v}$, antibiotik klindamisin $150 \mathrm{mg}$, dan pereaksi kimia. Bakteri uji yang digunakan dalam penelitian ini adalah bakteri Propionibacterium acnes. 


\section{Prosedur Penelitian}

\section{Pengambilan sampel dan determinasi daun glodokan tiang}

Sampel yang digunakan dalam penelitian ini diperoleh dari kampung pinang, jalan Pangeran Suryanata, kelurahan bukit pinang, Samarinda. Determinasi dilakukan di Laboratorium Anatomi dan Fisiologi, Fakultas Matematika dan IImu Pengetahuan Alam Universitas Mulawarman, Kalimantan Timur.

\section{Pembuatan simplisia serbuk daun glodokan tiang}

Daun glodokan tiang dikumpulkan kemudian dicuci dengan air mengalir setelah itu ditempatkan di wadah. Pengeringan dilakukan dengan cara diangin-anginkan sampai kering, setelah kering diblender hingga menjadi serbuk dan diayak dengan menggunakan ayakan mesh 60 .

\section{Pembuatan ekstrak etanol serbuk daun glodokan tiang}

Dalam penelitian ini metode ekstraksi yang digunakan adalah cara maserasi dengan pengulangan (remaserasi) menggunakan pelarut etanol $70 \%$. Pembuatan kontrol negatif DMSO $1 \%$ dengan cara larutan DMSO $1 \%(\mathrm{v} / \mathrm{v})$ dibuat dengan cara melarutkan $1 \mathrm{~mL}$ larutan DMSO kedalam air suling hingga $100 \mathrm{~mL}$. Pembuatan kontrol positif dibuat dengan cara serbuk klindamisin sebanyak $168 \mathrm{mg}$ dilarutkan dengan dimetil sulfoksida $1 \%(\mathrm{v} / \mathrm{v})$ sebanyak 10 $\mathrm{mL}$ aduk hingga homogen. Pembuatan sediaan uji ekstrak etanol daun glodokan tiang, yaitu

a) Konsentrasi $30 \%(\mathrm{~b} / \mathrm{v})=$ timbang ekstrak etanol daun glodokan tiang $300 \mathrm{mg}$ larutkan dengan dimetil sulfoksida 1\% (v/v) $1 \mathrm{ml}$ lalu diaduk hingga homogen.

b) Konsentrasi $40 \%(\mathrm{~b} / \mathrm{v})=$ timbang ekstrak etanol daun glodokan tiang 400 mg larutkan dengan dimetil sulfoksida $1 \%(\mathrm{v} / \mathrm{v}) 1 \mathrm{ml}$ lalu diaduk hingga homogen.

c) Konsentrasi $50 \%(\mathrm{~b} / \mathrm{v})=$ timbang ekstrak etanol daun glodokan tiang 500 mg larutkan dengan dimetil sulfoksida $1 \%(\mathrm{v} / \mathrm{v}) 1 \mathrm{ml}$ lalu diaduk hingga homogen.

\section{Skrining fitokimia ekstrak etanol daun glodokan tiang}

Pemeriksaan Alkaloid

Ekstrak ditimbang 0,5 gram dimasukkan kedalam tabung reaksi ditambahkan 1 $\mathrm{mL}$ asam klorida $2 \mathrm{~N}$ dan $9 \mathrm{~mL}$ air suling, dipanaskan di atas tangas air selama 2 menit dan didinginkan lalu disaring. Filtrat dipakai untuk percobaan berikut :

a) Diambil 3 tetes filtrat, lalu ditambahkan 2 tetes pereaksi Mayer menghasilkan endapan kuning putih.

b) Diambil 3 tetes filtrat, lalu ditambahkan 2 tetes pereaksi Bouchardat menghasilkan endapan coklat hitam.

c) Diambil 3 tetes filtrat, lalu ditambahkan 2 tetes pereaksi Dragendorf menghasilkan endapan merah bata.

Pemeriksaan Tanin

Ekstrak ditimbang 0,5 gram ditambah dengan $10 \mathrm{~mL}$ air suling, lalu filtratnya diencerkan sampai tidak berwarna. Diambil $2 \mathrm{~mL}$ larutan lalu ditambahkan 1-2 tetes pereaksi Ferri Klorida 1\%. Warna biru atau hijau kehitaman menunjukkan adanya tanin.

\section{Pemeriksaan Flavonoid}

Ekstrak ditimbang 0,5 gram ditambahkan $10 \mathrm{~mL}$ air suling panas, dididihkan selama 5 menit dan disaring dalam keadaan panas. Filtrat yang diperoleh diambil $5 \mathrm{~mL}$ lalu ditambahkan 0,1 gram serbuk Magnesium, $1 \mathrm{~mL}$ asam klorida pekat, dan $2 \mathrm{~mL}$ amil alkohol lalu dikocok dan dibiarkan memisah. Flavonoid positif jika terjadi 
warna merah, kuning, dan jingga pada lapisan amil alkohol.

\section{Pemeriksaan Saponin}

Ekstrak ditimbang 0,5 gram dimasukkan ke dalam tabung rekasi ditambahkan 10 $\mathrm{mL}$ air suling panas. Didinginkan lalu dikocok kuat-kuat selama 10 detik. Terbentuk busa selama tidak kurang 10 menit setinggi $1-10 \mathrm{~cm}$. Pada penambahan asam klorida pekat 1 tetes, apabila busa tidak hilang memberikan indikasi adanya saponin [8].

\section{Pembuatan media agar miring}

Ditimbang Nutrient Agar sebanyak 0,4 gram, agar sebanyak 1 gram, dan glukosa sebanyak 0,5 gram, kemudian dilarutkan dengan $50 \mathrm{~mL}$ aquadest dalam beaker glass. Dipanaskan diatas hotplate sambil diaduk secara perlahan hingga mendidih. Sebanyak $15 \mathrm{~mL}$ dituangkan masing-masing pada tabung reaksi steril dan ditutup dengan kapas. Kemudian media tersebut disterilkan dalam autoklaf pada suhu $121^{\circ} \mathrm{C}$ selama 15 menit, kemudian dibiarkan pada suhu ruangan selama 30 menit sampai media memadat pada kemiringan $30^{\circ} \mathrm{C}$. Media agar miring digunakan untuk inokulasi bakteri [9].

\section{Kultur bakteri pada media}

Bakteri uji diambil dengan ujung ose, lalu ditanamkan pada media agar miring dengan cara menggores secara zig-zag. Selanjutnya diinkubasi dalam inkubator pada suhu $37^{\circ} \mathrm{C}$ selama 24 jam [10].

\section{Pembuatan media Mueller Hilton Agar (MHA)}

Bubuk MHA ditimbang sebanyak 12,58 gram, dimasukkan kedalam beaker glass ditambahkan air $370 \mathrm{~mL}$. Letakkan diatas hotplate dan aduk menggunakan stirer. Setelah mendidih, dituang kedalam erlenmeyer dan ditutupi dengan aluminium foil. Selanjutnya disterilkan dalam autoklaf pada suhu $121^{\circ} \mathrm{C}$ selama 15 menit.

\section{Pembuatan Suspensi Propionibacterium acnes}

Bakteri

Diambil stok kultur bakteri Propionibacterium acnes menggunakan spatel yang telah steril lalu dimasukkan ke dalam beaker glass yang telah diisi dengan aquadest steril. Pengenceran dibuat dan diukur tingkat kekeruhannya suspensi dengan alat spektrofotometer UV-Visibel sampai diperoleh suspensi bakteri dengan nilai transmitan $70-75 \%$ pada panjang gelombang $600 \mathrm{~nm}$. Diambil suspensi bakteri Propionibacterium acnes sebanyak $100 \mu \mathrm{L}$ menggunakan mikropipet dan letakkan pada permukaan media MHA pada cawan petri kemudian di swab menggunakan cotton swab, diamkan selama 15 menit agar suspensi bakteri meresap kedalam media.

\section{Uji aktivitas antibakteri dengan metode kertas cakram}

Siapkan 7 cawan petri yang sudah disterilkan, setelah itu dihitung media MHA sebanyak $20 \mathrm{~mL}$ dan masukkan kedalam cawan kemudian didiamkan hingga memadat. Swab suspensi Propionibacterium acnes menggunakan cotton swab ke permukaan media hingga merata. Siapkan kertas cakram kemudian celupkan pada kontrol positif yaitu Klindamisin $1 \%$, celupkan pada kontrol negatif yaitu DMSO $1 \%(\mathrm{v} / \mathrm{v})$, kemudian celupkan pada PI (Perlakuan 1) yaitu ekstrak etanol daun glodokan tiang 30\%, celupkan pada PII (Perlakuan 2) yaitu ekstrak etanol daun glodokan tiang $40 \%$, dan celupkan pada PIII (Perlakuan 3) yaitu ekstrak etanol daun glodokan tiang $50 \%$ yang sebelumnya telah direndam pada ekstrak selama 15 menit. Letakkan dipermukaan media dan masing-masing konsentrasi dibuat 3 kali pengulangan pada setiap cawan. Sampel uji didiamkan sampai meresap pada media, kemudian diinkubasi pada suhu 
$37^{\circ} \mathrm{C}$ selama 24 jam. Selesai diinkubasi lalu diukur diameter daya hambat $(\mathrm{mm})$ menggunakan penggaris.

$$
\begin{aligned}
& \text { Pengukuran Zona Hambat } \\
& =\frac{\mathrm{n} 1+\mathrm{n} 2+\mathrm{n} 3}{3}
\end{aligned}
$$

Ket :

$\mathrm{n} 1=$ jarak tempuh zona hambat pertama

n2 = jarak tempuh zona hambat kedua

n3 $=$ jarak tempuh zona hambat ketiga

Diameter zona hambat yang diukur yaitu daerah jernih sekitar kertas cakram (tidak ada pertumbuhan bakteri), diukur dari satu ujung ke ujung yang lain dengan melalui tengah - tengah cakram [11].

\section{Analisa Data}

Metode pengumpulan data yang digunakan adalah uji eksperimen berupa data kuantitatif. Data kuantitatif berupa daya antibakteri yang terbentuk pada uji aktivitas antibakteri. Data yang berdistribusi normal diuji dengan menggunakan metode One-Way ANOVA.

\section{HASIL DAN PEMBAHASAN}

\section{Pengambilan dan Determinasi Daun Glodokan Tiang (Polyalthia Longifolia S.).}

Daun glodokan tiang diperoleh dari Kampung Pinang, jalan Pangeran Suryanata, Kelurahan Bukit Pinang, Samarinda. Daun glodokan tiang yang digunakan adalah daun glodokan tiang yang segar berwarna hijau tua dikarenakan pada daun yang tua seluruh kandungan zat aktif yang terdapat didalam daun tersebut telah sempurna. Pengambilan daun glodokan tiang dilakukan pada sore hari karena proses fotosintesis telah selesai[12]. Daun glodokan tiang yang digunakan dideterminasi di Laboratorium Anatomi dan Sistematika Tumbuhan, Fakultas MIPA, Universitas Mulawarman Samarinda. Tujuan dilakukan determinasi adalah untuk memastikan bahwa tumbuhan daun glodokan tiang yang akan digunakan dalam penelitian adalah benar tumbuhan yang diinginkan. Hasil determinasi yang didapat menunjukkan bahwa tanaman yang digunakan dalam penelitian ini adalah benar spesies Polyalthia longifolia (Sonn.) Thwaites.

\section{Pembuatan Simplisia Serbuk Daun Glodokan Tiang (Polyalthia Longifolia S.).}

Daun glodokan tiang segar diambil sebanyak $2 \mathrm{~kg}$ lalu di sortasi basah hal ini bertujuan untuk memisahkan antara daun dengan tangkai dan bagian tanaman yang rusak (dimakan ulat dan sebagainya). Pencucian dilakukan menggunakan air mengalir untuk menghilangkan kotoran pada daun glodokan tiang. Proses pengeringan simplisia daun glodokan tiang dilakukan dengan cara dikering anginkan di tempat terlindung dari sinar matahari langsung. Proses pengeringan bertujuan agar senyawa kimia tidak rusak atau terurai karena pemanasan oleh sinar matahari [12].

Pengeringan simplisia dapat dilakukan dengan cara alami maupun buatan. Pada umumnya suhu pengeringan adalah antara $40^{\circ} \mathrm{C}-60^{\circ} \mathrm{C}$. Pengeringan buatan yaitu dapat menggunakan oven, suhu optimum $40^{\circ} \mathrm{C}-50^{\circ} \mathrm{C}[13]$. Pengeringan yang dilakukan dalam penelitian ini secara alami yaitu dengan dikering anginkan. Selama proses pengeringan terdapat perubahan warna dan bobot dari sampel. Daun glodokan tiang yang segar berwarna hijau tua setelah dikeringkan berwarna kecoklatan. Proses pengeringan simplisia yang telah selesai kemudian disortasi kering untuk memisahkan pengotor lain yang masih tertinggal[14]. Hasil dari pengeringan didapat simplisia seberat $255,146 \mathrm{~g}$. Susut pengeringan dari simplisia daun glodokan tiang yaitu sebesar $12,75 \%$. 
Simplisia daun glodokan tiang kemudian dihaluskan menggunakan blender. Serbuk yang diperoleh sebanyak 254,97 gram selanjutnya diayak hingga diperoleh serbuk dengan derajat kehalusan tertentu yaitu menggunakan pengayak mesh nomor 60. Alasan penggunaan mesh nomor 60 adalah untuk diperoleh serbuk halus [15]. Tujuan dari penyerbukan agar ukuran partikel menjadi lebih kecil sehingga dapat memperluas kontak dan meningkatkan daya interaksinya dengan pelarut. Kondisi ini akan menyebabkan kecepatan untuk mencapai kesetimbangan sistem menjadi lebih besar [16].

\section{Pembuatan Ekstrak Etanol Serbuk Daun Glodokan Tiang(Polyalthia Longifolia S.).}

Ekstraksi serbuk daun glodokan tiang menggunakan metode maserasi. Metode maserasi merupakan metode yang sederhana, lebih mudah dilakukan dan murah[17]. Maserasi merupakan cara penarikan zat aktif yang tidak menggunakan pemanasan sehingga kandungan senyawa yang terdapat pada daun glodokan tiang dapat stabil dan terhindar dari kerusakan akibat proses pemanasan selama ekstraksi.

Sebanyak 200 gram serbuk simplisia daun glodokan tiang di ekstraksi menggunakan pelarut etanol $70 \%$ sebanyak 2L. Alasan menggunakan pelarut etanol $70 \%$, karena etanol $70 \%$ merupakan pelarut universal yang dengan baik melarutkan senyawa kimia dalam tumbuhan baik senyawa polar maupun nonpolar[18]. Ekstrak cair yang diperoleh kemudian dipekatkan dengan cara menggunakan vakum rotary evaporator sehingga didapatkan ekstrak kental yang berwarna hijau tua atau kehitaman. Berat ekstrak kental yang diperoleh dari 200 gram serbuk simplisia yaitu 49,42 g sehingga rendemen yang diperoleh sebesar $24,71 \%$.

\section{Skrining fitokimia ekstrak etanol daun glodokan tiang}

Skrining fitokimia dilakukan untuk mengetahui adanya kandungan senyawa metabolit sekunder yang terkandung dalam ekstrak daun glodokan tiang (Polyalthia Longifolia S.). Golongan metabolit sekunder yang diperiksa adalah alkaloid, flavonoid, tanin, dan saponin. Hasil pengujian skrining fitokimia terhadap ekstrak daun glodokan tiang dapat dilihat pada Tabel 1 berikut:

Tabel 1. Hasil Skrining Fitokimia EkstrakEtanol Daun Glodokan Tiang (Polyalthia Longifolia S.)

\begin{tabular}{c|c|c|c|c}
\hline $\begin{array}{c}\mathbf{N} \\
\mathbf{0}\end{array}$ & $\begin{array}{c}\text { Uji } \\
\text { Fitokimia }\end{array}$ & Pereaksi & Hasil & Simpulan \\
\hline 1 & Alkaloid & $\begin{array}{c}\text { Mayer } \\
\text { Bouchardat } \\
\text { Dragendorf }\end{array}$ & $\begin{array}{c}\text { Putih } \\
\text { Coklat } \\
\text { Merah } \\
\text { bata }\end{array}$ & $\begin{array}{c}(-) \\
(+) \\
(+)\end{array}$ \\
\hline 2 & Flavonoid & $\begin{array}{c}\mathrm{HCl} \text { pekat, } \\
\text { Serbuk Mg, } \\
\text { Amil Alkohol }\end{array}$ & Jingga & $(+)$ \\
\hline 3 & Tanin & FeCl31\% & $\begin{array}{c}\text { Biru/ hijau } \\
\text { kehitama } \\
\mathrm{n}\end{array}$ & $(+)$ \\
\hline 4 & Saponin & Air $+\mathrm{HCl} 2 \mathrm{~N}$ & $\begin{array}{c}\text { Busa } \\
\text { permanen }\end{array}$ & $(+)$ \\
\hline
\end{tabular}

Berdasarkan Tabel 1, menunjukkan bahwa ekstrak etanol daun glodokan tiang memiliki metabolit sekunder alkaloid, flavonoid, tanin, dan saponin. Hal ini sesuai dengan penelitian yang telah dilakukan sebelumnya bahwa senyawa aktif yang terdapat pada daun glodokan tiang adalah alkaloid, flavonoid, tannin dan saponin [6].

Hasil skrining fitokimia memperlihatkan bahwa ekstrak etanol daun glodokan tiang memiliki senyawa golongan alkaloid. Pada pereaksi mayer didapatkan hasil negatif karena tidak terbentuknya endapan putih, sedangkan pada pereaksi Bouchardat mendapatkan hasil positif dengan terbentuknya endapan coklat dan pereaksi Dragendorf mendapatkan hasil positif dengan terbentuknya endapan merah bata. Menurut penelitian hasil 
pengujian alkaloid dapat dikatakan positif jika terjadi endapan paling sedikit dua dari tiga percobaan di atas [19]. Apabila kurang dari 2, dari 3 percobaan maka dikatakan negatif alkaloid. Dapat disimpulkan bahwa ekstrak etanol daun glodokan tiang dikatakan positif alkaloid.

Senyawa golongan flavonoid pada ekstrak etanol daun glodokan tiang mendapatkan hasil yang positif. Dibuktikan dengan terbentuknya lapisan berwana jingga. Penambahan serbuk magnesium dan asam klorida pada pengujian flavonoid akan menyebabkan tereduksinya senyawa flavonoid yang ada sehingga menimbulkan reaksi warna merah yang merupakan ciri adanya flavonoid [8].

Senyawa golongan tanin pada ekstrak etanol daun glodokan tiang mendapatkan hasil yang positif, dibuktikan dengan terbentuknya larutan berwarna biru atau hijau kehitaman. Senyawa golongan saponin pada ekstrak etanol daun glodokan tiang mendapatkan hasil yang positif. Dibuktikan dengan terbentuknya busa yang permanen selama tidak kurang 10 menit dan tidak hilang jika diteteskan asam klorida pekat [20].

\section{Uji Aktivitas Antibakteri Ekstrak Etanol Daun Glodokan Tiang (Polyalthia Longifolia S.) Terhadap Bakteri Propionibacterium acnes.}

Uji aktivitas antibakteri ekstrak etanol daun glodokan tiang dilakukan untuk mengetahui pengaruh ekstrak etanol daun glodokan tiang (Polyalthia Longifolia S.) terhadap pertumbuhan bakteri Propionibacterium acnes. Konsentrasi ekstrak etanol daun glodokan tiang yang digunakan pada penelitian ini adalah $30 \%, 40 \%$, dan $50 \%$. Alasan pemilihan konsentrasi ini ialah berdasarkan pada penelitian[7], yaitu untuk mengetahui konsentrasi efektif ekstrak etanol daun glodokan tiang yang efektif menghambat pertumbuhan bakteri Escherichia coli. Metode yang digunakan pada pengujian
Vol. 7. No.1 Juni 2018

ini adalah metode difusi cakram. Dasar pemilihan metode ini karena memiliki kelebihan yaitu mudah dilakukan, tidak memerlukan peralatan khusus dan relatif [21].

Pada penelitian ini menggunakan media MHA (Mueller Hillton Agar) karena merupakan media yang biasa digunakan dalam uji antibakteri dimana bakteri dapat hidup dalam media tersebut[22]. MHA juga merupakan media yang telah direkomendasikan oleh FDA dan WHO untuk tes antibakteri terutama bakteri aerob dan bakteri anaerob fakultatif [23].

Pengukuran zona hambat bakteri Propionibacterium acnes terhadap ekstrak etanol daun glodokan tiang dengan konsentrasi $30 \%, 40 \%$, dan $50 \%$ serta antibiotik klindamisin $150 \mathrm{mg}$ sebagai kontrol positif dan dimetil sulfoksida $1 \%$ sebagai kontrol negatif terhadap dapat dilihat pada tabel 2 .

Hasil dari perlakuan kontrol negatif yang menggunakan dimetil sulfoksida $1 \%$ tidak terlihat zona hambat, hal ini terjadi dikarenakan dimetil sulfoksida berfungsi untuk mengetahui ada tidaknya pengaruh pelarut terhadap pertumbuhan bakteri Propionibacterium acnes dan cairan ini bersifat tidak toksik sehingga tidak memberikan daya hambat pertumbuhan bakteri dan tidak mengganggu hasil pengujian aktivitas antibakteri [24]. 
Tabel 2. Hasil Pengukuran Zona Hambat Bakteri Propionibacterium acnes Terhadap Ekstrak Etanol Daun Glodokan Tiang (Polyalthia Longifolia S.)

\begin{tabular}{c|c|c}
\hline $\begin{array}{c}\text { Konsentrasi } \\
\text { Ekstrak } \\
\text { Etanol Daun } \\
\text { Glodokan } \\
\text { Tiang }\end{array}$ & $\begin{array}{c}\text { Rata-Rata } \\
\text { Diameter } \\
\text { Zona } \\
\text { Hambat } \\
(\mathbf{m m})\end{array}$ & $\begin{array}{c}\text { Kriteria } \\
\text { Zona } \\
\text { Hambat }\end{array}$ \\
\hline $\begin{array}{c}\text { DMSO 1\%( K } \\
(-))\end{array}$ & 0 & Lemah \\
\hline $30 \%(\mathrm{P} 1)$ & $8,83 \mathrm{~mm}$ & Sedang \\
\hline $40 \%(\mathrm{P} 2)$ & $9 \mathrm{~mm}$ & Sedang \\
\hline $50 \%(\mathrm{P3})$ & $10,5 \mathrm{~mm}$ & Kuat \\
\hline $\begin{array}{l}\text { Klindamisin } \\
1 \%(\mathrm{~K}(+))\end{array}$ & $33,16 \mathrm{~mm}$ & Sangat \\
Kuat
\end{tabular}

Hasil dari perlakuan kontrol positif yaitu Klindamisin terbentuk zona hambat yang paling besar dengan zona hambat sebesar 33,16 mm, hal ini dikarenakan Klindamisin merupakan antibiotik yang memiliki spektrum luas yang efektif dapat menghambat bakteri gram positif dan gram negatif. Klindamisin merupakan golongan antibiotik yang paling banyak digunakan dalam pengobatan jerawat selain golongan antibiotik lain seperti tetrasiklin dan erithromisin. Mekanisme kerja Klindamisin yaitu menghambat sistesis protein dari mikroba dengan cara terikat pada subunit 50S [25]. Kontrol positif (DMSO) berfungsi sebagai kontrol dari zat uji untuk mengetahui perbandingan diameter zona hambat yang terbentuk dengan ekstrak. Control positif juga membuktikan bahwa DMSO yang digunakan untuk melarutkan ekstrak etanol daun glodokan tiang tidak mempunyai aktivitas terhadap bakteri uji.

Pemberian ekstrak etanol daun glodokan tiang (Polyalthia Longifolia S.) memiliki efek antibakteri terhadap bakteri Propionibacterium acnes yang dibuktikan dengan terbentuknya zona hambat yaitu area bening yang tidak ditumbuhi oleh bakteri. Menurut penelitian terdahulu, apabila zona hambat yang terbentuk memiliki diameter sebesar 0-5 $\mathrm{mm}$ maka daya antibakterinya dikatakan lemah, diameter sebesar 5-10 mm dikatakan sedang, sedangkan 10-20 mm dikatakan kuat, dan >20 mm dikatakan sangat kuat [26].

Berdasarkan hasil uji aktivitas antibakteri ekstrak etanol daun glodokan tiang (Polyalthia Longifolia S.) menunjukkan bahwa masing-masing konsentrasi yaitu pada konsentrasi 30\% ekstrak etanol daun glodokan tiang ratarata zona hambat yang terbentuk sebesar $8,83 \mathrm{~mm}$, konsentrasi $40 \%$ ratarata zona hambat yang terbentuk sebesar $9 \mathrm{~mm}$, konsentrasi $50 \%$ ratarata zona hambat yang terbentuk sebesar 10,5 mm. Dalam penelitian ini semakin meningkatnya konsentrasi, semakin meningkat pula daya hambat yang dihasilkan. Hal ini sesuai dengan penelitian [23] yang menyatakan bahwa semakin tinggi konsentrasi yang digunakan maka semakin tinggi daya hambatnya. Hal ini dikarenakan semakin tinggi konsentrasi semakin banyak kandungan bahan aktif antibakterinya. Keefektifan suatu zat antimikroba dalam menghambat pertumbuhan tergantung pada sifat mikroba uji, dan konsentrasi dan lamanya waktu kontak [27].

Berdasarkan kriteria zona hambat hasil yang diperoleh dari pengujian ekstrak etanol daun glodokan tiang terhadap bakteri Propionibacterium acnes untuk konsentrasi $30 \%$ dan $40 \%$ daya antibakterinya dapat dikatakan sedang, dan pada konsentrasi $50 \%$ daya antibakterinya dapat dikatakan sangat kuat.

Zona hambat yang dihasilkan dari ekstrak etanol daun glodokan tiang dapat dihubungkan dengan senyawasenyawa yang terkandung didalamnya. Senyawa aktif yang terdapat pada daun glodokan tiang adalah alkaloid, flavonoid, dan tanin[6]. Hal ini sesuai dengan hasil yang didapatkan dalam penelitian yaitu senyawa alkaloid, 
flavonoid, dan tanin yang dapat menghambat pertumbuhan bakteri Propionibacterium acnes. Flavonoid berfungsi sebagai bakteriostatik dan mekanisme kerjanya membentuk senyawa kompleks dengan protein dan terlarut sehingga dapat merusak membran sel bakteri [28]. Tanin memiliki aktivitas sebagai antibakteri. Mekanisme kerjanya dengan cara mengkerutkan dinding sel itu sendiri, sel tidak dapat melakukan aktivitas hidup sehingga pertumbuhan terhambat atau bahkan mati [29]. Senyawa alkaloid memiliki mekanisme penghambatan dengan cara mengganggu komponen penyusun peptidoglikan pada sel bakteri, sehingga lapisan dinding sel tidak terbentuk secara utuh dan menyebabkan kematian sel tersebut [30].

Setelah didapatkan hasil dari uji aktivitas antibakteri, selanjutnya dilakukan analisis data. Hasil analisis statistik dapat dilihat pada tabel 3.

Tabel 3. Hasil Analisis Statistik

\begin{tabular}{c|l|c}
\hline No & \multicolumn{1}{|c|}{ Uji Statistik } & $\begin{array}{c}\text { Nilai } \\
\text { Signifikansi } \\
\text { (p) }\end{array}$ \\
\hline 1 & $\begin{array}{l}\text { Uji distribusi } \\
\text { normal (Uji }\end{array}$ & 0,637 \\
& Saphiro Wilk) & \\
\hline 2 & Uji homogenitas & 0,062 \\
\hline 3 & Uji Anova & 0,000 \\
\hline 4 & Uji LSD & 0,006 \\
\hline
\end{tabular}

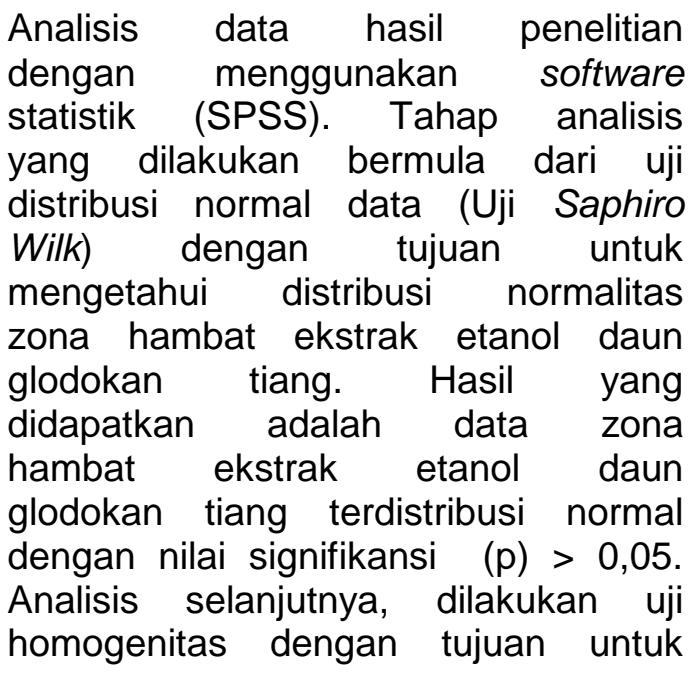

Vol. 7. No.1 Juni 2018

mengetahui homogenitas rata-rata zona hambat ekstrak etanol daun glodokan tiang. Hasil uji statistik diperoleh dari uji homogenitas diperoleh data zona hambat ekstrak etanol daun glodokan tiang homogeny, hal ini dilihat dari nilai signifikansi $(p)>0,05 . \quad$ Uji berikutnya adalah uji anova dengan tujuan untuk mengetahui adanya perbedaan rata-rata dari zona hambat ekstrak glodokan tiang. Hasil yang diperoleh dari uji statistik adalah terdapat perbedaan ratarata dari zona hambat dengan nilai signifikansi $(p)<0,05 . \quad$ Analisis yang terakhir adalah dilakukan analisis post hoc dengan uji LSD, bertujuan untuk mengetahui adanya perbedaan bermakna dari rata-rata zona hambat tiap konsentrasi. Hasil uji LSD yang diperoleh adalah bahwa tiap konsentrasi memiliki perbedaan dengan nilai signifikansi $p<0,05$.

\section{KESIMPULAN DAN SARAN}

\section{Kesimpulan}

1. Ekstrak etanol daun glodokan tiang memiliki aktivitas antibakteri terhadap bakteri Propionibacterium acne pada konsentrasi $30 \%, 40 \%$, dan $50 \%$ masing-masing memiliki zona hambat sebesar $8,83 \mathrm{~mm}, 9$ $\mathrm{mm}$, dan $10,5 \mathrm{~mm}$.

2. Konsentrasi maksimal ekstrak etanol daun glodokan tiang yang efektif menghambat pertumbuhan bakteri Propionibacterium acnes sebesar $50 \%$.

\section{Saran}

Perlu dilakukan penelitian lebih lanjut dengan menggunakan metode sumuran.

\section{UCAPAN TERIMAKASIH}

Pada kesempatan ini penulis mengucapkan terimakasih kepada Ristek Dikti yang memberikan 
kesempatan kepada penulis dengan memberikan dana hibah melalui Program Penelitian Dosen Pemula periode tahun 2017.

\section{DAFTAR PUSTAKA}

[1] Harper JC. 2004. An Update on The Pathogenesis and Management of Acne Vulgaris. JAAD. 51(1):36-38. doi 101016/j.jaad.2004.01.023

[2] Zaenglein AL, Graber EM, Thiboutot DM. 2008. Acne vulgaris and Acneiform Eruptions. Fitzpatrick's Textbook of Dermatology. 8th ed. New York: Mc Graw Hill.

[3] Humphrey S. 2012. Antibiotic Resistance in Acne Treatment. US National Library of Medicine and Pubmed. 17(9): 4-10.

[4] Marthanda MM, Subramanyam M, Hima BM, dan Annapurna J. 2005. Antimicrobial Activity of Clerodane diterpenoids from Polyalthia longifolia L. Fitoterapia. 76(3-4) : 336-339. doi 10.1017/j.fitote.2005.02.005

[5] Parvin A, Akter J, Hassan MMd, Biswas N. 2013. Study on the comparative antibacterial activity of Polyalthia longifolia (Debdaru) leaf extracts to some selective pathogenic bacterial strains. International Journal of Biosciences. 3(5) : 17-24. doi : 10.12692/ijb/3.5.17-24

[6] Manasa M, Vivek M N, Kambar, YR, Onkarappa, Kekuda PTR. 2014. Antimicrobial Activity of Leaf And Pericarp Extracts of Longifolia (Annonaceae). JPSI. 3(3) : 221225. doi : 10.7897/22774572.033143

[7] Nur MR. 2016. Uji Aktivitas Antibakteri Ekstrak Etanol Daun Glodokan Tiang (Polyalthia longifolia L). Terhadap Bakteri
Eschericia coli. (Karya Tulis Ilmiah). Samarinda: Akademi Farmasi.

[8] Tiwari P. Kumar B. Kaur, M. Kaur, G. Kaur, H. 2011. Phytochemical Screening and Extraction : A Review. International Pharmaceutica Sciencia.1 (1):98106.

[9] Kumesan YAN, Yamelan PVY Supriati HS. 2013. Formulasi dan Uji Aktivitas Gel Antijerawat Ekstrak Umbi Bakung (Crinum Asiaticum L.) Terhadap Bakteri Staphylococcus Aureus Secara In Vitro. Pharmacon. 2(02):18-26.

[10] Anggraini, D., Rahmawati, N., dan Hafsah, S. 2013. Formulasi Gel Antijerawat dari Ekstrak Etil Asetat Gambir. Jurnal Penelitian Farmasi Indonesia.

[11] Merta, I. W., Nuidja, I. N., dan NM, Marwati. 2013. "Ekstrak Gambir Memiliki Daya Hambat Terhadap Pertumbuhan Staphylococcus aureus secara invitro". Skala Husada. Vol: 10 (1). Hal: 39.

[12] Feni, D. H. W. 2015. "Uji Aktivitas Antibakteri Ekstrak Etanol Daun Kokang (Lepisanthes amoena (Hassk.) Leenh) Terhadap Bakteri Staphylococcus epidermis". Karya Tulis IImiah. Samarinda: Akademi Farmasi.

[13] Sembiring, Bagem Br. 2007. Teknologi Penyiapan Simplisia Terstandar Tanaman Obat. Balai Penelitian Tanaman Obat dan Rempah (BALITTRO). Warta Penelitian dan Pengembangan Tanaman Industri. Vol: 13 (2).

[14] Musaenah. 2016. "Uji Aktivitas Antibakteri Ekstrak Air Kulit Bawang Merah (Allium cepa L.) Terhadap Bakteri Propionibacterium acnes". Karya 
Tulis IImiah. Samarinda: Akademi Farmasi.

[15] Departemen Kesehatan Republik Indonesia. 2008. Farmakope Herbal Indonesia. Edisi I. Jakarta: Depkes RI. Hal: 172

[16] Departemen Kesehatan Republik Indonesia. 2000. Parameter Standar Umum Ekstrak Tumbuhan Obat. Jakarta: Depkes RI.

[17] Marjoni, M. R. 2016. Dasar-Dasar Fitokimia Untuk Diploma III Farmasi. Jilid 1. Jakarta: CV Trans Info Media

[18] Voight, R. 1994. Buku Pelajaran Teknologi Farmasi edisi V. Yogyakarta: Universitas Gajah Mada Press.

[19] Budiyanti, 2016. "Uji Aktivitas Antibakteri Ekstrak Etanol Daun Lakum (Cayratia trifolia Linn) Terhadap Staphylococcus aureus. Karya Tulis IImiah. Samarinda : Akademi Farmasi Samarinda.

[20] Widiastuti, A.E.S., Sri, R.D.A., Ashadi., Bakti.M., Cici.P.R. 2014. Skrining Fitokimia dan Identifikasi Komponen Utama Ekstrak Metanol Kulit Durian (Durio zibethinus Murr.) Varietas Petruk. Surakarta: Makalah Pendamping Seminar Nasional Kimia dan Pendidikan Kimia VI

[21] Jawetz, M., dan Adelberg. 2005. Mikrobiologi Kedokteran. Diterjemahkan oleh Huriawati Hartanto. Edisi 23. Jakarta: EGC. Hal: 43, 225-228.

[22] Fatimah, S. Ningsih, Y., Prasetya, Y, dan Munandar, A. 2014. "Efektivitas Ekstrak Daun Katuk (Sauropus androgyrus L.) dalam Menghambat Pertumbuhan Bakteri Staphylococcus aureus Secara In Vitro". Yogyakarta:
Jurnal Yogyakarta Stikes Guna Bangsa. Hal: 3

[23] Kusumawati, E., Supriningrum, R., Rozadi, R. 2015. Uji Aktivitas Antibakteri Ekstrak Etanol Daun Kecombrang Etlingera elatior (Jack) R.M.Sm Terhadap Salmonella typhi. Manuntung. Vol: 1 (1). Hal: 1-7.

[24] Pratiwi, T. Sylvia. 2008. Mikrobiologi Farmasi. Jakarta: Erlangga.

[25] Ariska, N. A., Suswati, E., Misnawi. 2016. Uji In Vitro Ekstrak Etanol Biji Kakao (Theobroma cacao) sebagai Antibakteri terhadap Propionibacterium acnes. e-Jurnal Pustaka Kesehatan. Vol 4: (1)

[26] Nazri, N.A.A.M., Ahmat, N., Adnan, A.S.A., Mohamad, S.S.A., Ruzaina, S.S.A. 2011. In Vitro Antibacterial and Radical Scaveing Activities Malaysian Table Salad. African Journal of Biotechnology. Vol. 10(30), pp. 5728-5735. Malaysia.

DOI : 10.5897/AJB11.227

[27] Jenie, B. S. L. dan Kuswanto.1994. Aktivitas antimicroba dari pigmen angkak yangdiproduksi oleh Monasnrs purpuracs terhadap beberapa microba patogen dan perusak makanan. Prosiding Pertemuan Ilmiah Tahunan Permi.

[28] Nuria M. C., A. Faizatun., dan Sumantri. 2009. Uji Antibakteri Ekstrak Etanol Daun Jarak Pagar (Jatropha cuircas L) terhadap Bakteri Staphylococcus aureus ATCC 25923, Escherichia coli ATCC 25922, dan Salmonella typhi ATCC 1408. IImu-ilmu Pertanian. Vol: 5. Hal: 26-37

[29] Ajizah, A. 2004. Sensitivitas Salmonella typhimurium Terhadap 
Ekstrak daun Jambu Biji (Psidium

Guajava L). Bioscientie. Vol 1: (1)

[30] Juliantina, F. R., Ayu, D.C.M., Nirwani, B., Nurmasitoh, T., Tri, B.E. 2008. Manfaat sirih merah (piper crocatum) sebagai agen anti bakterial terhadap bakteri gram positif dan gram negatif. JKKI - Jurnal Kedokteran dan Kesehatan Indonesia.Vol 1: (3). 


JFL
Jurnal Farmasi Lampung $\quad$ Vol. 7. No.1 Juni 2018

